\title{
LOS ALCALDES MAYORES DE CATALUÑA: UNA EVOLUCIÓN DESIGUAL Y CONFLICTIVA (1717-1808)
}

\author{
por \\ RAFAEl CerRo NARgÁNEZ \\ Universidad de Barcelona
}

RESUMEN: Este artículo analiza la evolución de los alcaldes mayores o tenientes de corregidor de Cataluña entre los años 1717 y 1808. Tras liquidar Felipe V el marco jurídico-foral catalán, el Decreto de Nueva Planta estableció veinte varas de alcalde mayor. Sin embargo su importancia no ba sido valorada bien hasta boy en día. Es cierto que el alcalde mayor no se puede entender sino es por la presencia de los corregidores militares, a los que asesoraba en materia de justicia civil y criminal de primera instancia y le substituia en los cabildos durante sus ausencias. Pero no es menos cierto que aquí era donde residía su verdadera importancia, la cual, sin embargo, no se tradujo en un mayor peso específico dentro de la administración borbónica. A través de los Decretos de Nueva Planta, Ordenanza de IntendentesCorregidores de 1749 y el Decreto de 23 de marzo de 1783, hemos realizado una valoración global sobre la articulación de este empleo castellano en tierras catalanas. Sus problemas profesionales, eternización en corregimientos y alcaldías y como se truncaron buena parte de sus espectativas de ascensos a tribunales reales (Audiencias y Chancillerías).

PALABRAS ClAVE: · Instituciones. Administración. Alcaldes Mayores. Cataluña. España.

\footnotetext{
1 El presente artículo ha sido realizado gracias a la ayuda de una beca predoctoral concedida por la "Fundación Caja Madrid" (Convocatoria, 1999-2000), que se enmarca en mi proyecto de tesis doctoral titulado: «Los alcaldes mayores de Barcelona (1718-1808)». Las principales siglas utilizadas para este trabajo son las siguientes:

- ACA: Archivo de la Corona de Aragón.

- AHCB: Archivo Histórico de la Ciudad de Barcelona.

- BUB: Biblioteca Universitaria de Barcelona.
} 
ABSTRACT: This article analyses the evolution of the alcaldes mayores or tenientes de corregidores in Catalonia between 1717 and 1808, beginning at the moment when Philip V imposed the Decree of the Nueva Planta, abolishing the fueros of Catalonia and establishing the new position of the alcaldes mayores. Through a study of this decree, together with the Ordinance of Intendentes-Corregidores of 1749 and the decree of March 23, 1783, the article assesses the importance of these Castilian magistrates in Catalonia. It analyses the most important characteristics of the Catalonian alcaldes mayores, including their origin, profession, and important problems facing them such as the scarce possibilities of promotion in the royal tribunals.

KEY WORDS: Institutions. Administration. Alcaldes Mayores. Catalonia. Spain.

\section{INTRODUCCIÓN}

Los alcaldes mayores o tenientes de corregidor - como gustaba indistintamente definirlos- merecen en este trabajo una especial atención que debe ser justificada. De entrada la escasez de estudios monográficos es, de por si, una buena escusa para dedicarles íntegramente este artículo ${ }^{2}$. Pero además es una excelente oportunidad para ofrecer un poco de luz sobre una figura que, si bien poco conocida, formaba parte de esa carrera de varas que los Borbones trataron de dignificar profesionalmente con sus reformas ilustradas. Puede parecer insólito el marco geográfico que nos hemos propuesto estudiar, es decir Cataluña. Básicamente porque esta magistratura castellana era ajena al ordenamiento jurídico-foral catalán y porque además fue impuesta militarmente por la fuerza de las armas borbónicas una vez finalizado el conflicto dinástico. Pero creemos que esta circunstancia la convierten en más interesante como base explicativa de la evolución específica que adoptó, durante el siglo XVIII, en tierra extraña.

\section{LAS PRIMERAS VARAS DE LA NUEVA PLANTA}

Sin la menor duda hay que atribuir al intendente José Patiño y al consejero de Castilla Francisco Ametller, el diseño de la novel estructura administrativa en la que se inspiró la planta catalana para reajustar el complejo mosaico de veguerías y subveguerías repartidas por todo el país antes de 1716 . Siguiendo el modelo militarista impuesto por Felipe V a Valencia y Aragón en 1707; el Decreto de Nueva Planta articuló el Principado en doce corregimientos ${ }^{3}$. A su

2 Una excepción en BernARdo AREs, José Manuel de: Los alcaldes mayores de Córdoba (17501833), Córdoba 1978, 70 págs.

3 Siguen siendo fundamentales para el estudio de esta etapa los trabajos de MERCADER I RIBA, Joan: Felip V $i$ Catalunya, Barcelona 1968, págs. 25-32; TORRAS I RIBE, Josep Maria: Els municipis catalans de l'Antic Règim (1453-1808), Barcelona 1982, págs. 143-221; y GAY EsCODA, Josep Ma-

Hispania, LXI/1, núm. 207 (2001) 289-314 
vez éstos incorporaron nueve capitales de alcaldía, también cabezas de partido, es decir: Granollers, Basalú, Camprodón, Balaguer, Tárrega, Montblanc, Igualada, Agramunt y Berga. Excepto Talarn y el distrito especial del Valle de Arán, todos los demás corregimientos tenían asignados alcaldes mayores ${ }^{4}$. En total veinte varas moldeadas al estilo de las de Castilla. Más del doble de las desplegadas por los Borbones en los corregimientos valencianos y aragoneses, los cuales tuvieron que conformarse con tan sólo nueve de estas tenencias ${ }^{5}$. No obstante no podemos decir que la dinámica que impulsó su designación se hiciese siguiendo un criterio uniforme. En algunos casos, sabido es que se optó por una política deliberadamente ambigua que se concretó en la pugna sostenida por Besalú-Figueras y Camprodón-Olot por disponer de su propia Curia. En un principio se impusieron Besalú y Camprodón gracias a su antigua condición de capital de veguería real, cosa que, por ejemplo, no era la villa de Olot. Pero esta capitalidad será fuertemente contestada a lo largo de la centuria ${ }^{6}$.

Por lo general la mayoría de corregimientos catalanes tenían asignados dos alcaldes mayores. No así Puigcerdá y Tortosa que carecían de capitales de alcaldía y por consiguiente sólo disponían de una vara. Cervera, en un principio corregimiento de letras, fue un caso singular. Como cabeza de partido nunca tuvo alcaldes mayores a pesar de lo dispuesto en la Nueva Planta, teniendo que conformarse su corregidor - aun siendo militar - con un simple asesor letrado. Sin embargo éste retuvo hasta 1749 la facultad de nombrar la vara de su alcaldía en Agramunt. Barcelona tampoco tenía una capital de alcaldía ajena a ella. Su reducida superficie —una vez segregados los partidos judiciales de Mataró y Granollers- limitaban considerablemente su jurisdicción. Pero su especial estatus le permitió disponer de dos alcaldes mayores residentes en la ciudad. Uno para las causas civiles y otro para las criminales. En este aspecto las varas de Barcelona fueron equiparadas a las de otras capitales como: Madrid, Murcia, Cádiz, Córdoba, Granada y Málaga; además de Valencia y Zaragoza

ria: La Gènesi del Decret de Nova Planta» en Revista Jurídica de Cataluña (Barcelona) 1-2 (1982), págs. 263-348.

${ }^{4}$ BURGUEÑo, Jesús: De la vegueria a la província. La formació de la divisió territorial contemporània als països catalans (1790-1850), Barcelona 1995. pág. 22.

5 Para el ámbito de la Corona de Aragón sus nombres en Cataluña eran: Agramunt, Balaguer, Barcelona (dos varas), Berga, Besalú, Camprodón, Gerona, Granollers, Igualada, Lérida, Manresa, Mataró, Montblanc, Puigcerdá, Tarragona, Tárrega, Tortosa, Vic y Villafranca del Penedés. En Valencia: Alcira, Alicante, Castellón de la Plana, Morella, Orihuela, San Felipe, Valencia (dos varas) y Jijona. En Aragón: Calatayud, Cinco Villas, Alcaniz, Daroca, Huesca, Jaca, Teruel y Zaragoza (dos varas). Mallorca únicamente tuvo la alcaldía mayor de Palma. GómEz Rivero, Ricardo: Las competencias del ministerio de justicia en el Antiguo Régimen en Documentación Jurídica (Madrid) 65-66 (1990), págs. 153-154.

6 TORRAS I RIBE, Josep Maria:«El conflicte sobre la capitalitat de les demarcacions corregimentals de I'antic comptat de Besalú durant el segle XVIII" en Amics de Besalú, IV Assemblea d'Estudis del seu comtat, (Camprodón) 2 (1980), págs. 165-177. 
dentro de la Corona de Aragón`. En línea opuesta estaba Lérida que unida a Balaguer y Tárrega fue el único corregimiento catalán con tres alcaldes mayores.

Posiblemente el factor humano debió de comportar cambios más substanciales que el marco territorial. Así pues, durante la primera mitad del siglo XVIII, la reglamentación establecida en 1680 por un Auto Acordado del Consejo de Castilla reguló, en estos años, que el corregidor nombrase a sus respectivos alcaldes mayores en consideración al control que ejercía sobre todos «los oficios de justicia y jurisdicción civil y criminal, alcaldía y alguazilazgo» ${ }^{8}$. Por lo tanto el corregidor de Cataluña, con frecuencia gobernador militar de la plaza, debido a su condición castrense acostumbró a delegar en los alcaldes, mayores una parte de la jurisdicción real ordinaria, en especial aquella en materia de justicia civil y criminal de primera instancia ${ }^{9}$. No sabemos que criterios llevaban a un corregidor militar a nombrar letrados concretos, porque el Consejo de Castilla - en esta etapa - sólo se limitaba aprobar los despachos y tomar juramentos. Mientras que la Cámara se encargaba de conceder licencias y expedir títulos reales. En cambio la finalidad de la Real Hacienda era registrar la media annata ${ }^{10}$. Lógicamente el candidato a ocupar una vara de alcalde mayor, debía reunir una serie de requisitos no siempre fáciles de cumplir. Aunque derogadas las leyes de extranjería, fue preocupación de los Borbones intentar que los alcaldes mayores fuesen todos de origen castellano como los corregidores y la mayor parte de magistrados civiles y militares importantes del país ${ }^{11}$. Pero la distancia, el desconocimiento del territorio, la lengua, el derecho civil catalán - no suprimido - o la escasa remuneración debieron disuadir a muchos letrados castellanos de prestar servicios en varas catalanas. Contra todo pronóstico

7 CERRo NARGÁNEZ, Rafael: «Civiles ente militares: Los alcaldes mayores de Barcelona» en Pedralbes (Barcelona) 15 (1995), págs. 353-359.

${ }^{8}$ La consulta del Consejo estaba fechada el 2 de julio de 1680. Novísima Recopicación de la leyes de España, Madrid 1805-1807 (Edición facsímil, 1975), Lib. VII, Tit. XI, Ley. XIX.

9 GONZÁlez ALONSO, Benjamín: El corregidor castellano (1348-1808) Madrid 1970, pág. 92. No olvidemos además que según la Real Cédula Instructoria del año 1718, el alcalde mayor presidía los acuerdos municipales en ausencia del corregidor, previo juramento del empleo en el ayuntamiento y presetación de fiadores para el Juicio de Residencia. BUB: Colección de Ordenanzas, Pragmáticas y Reales Ordenes, vol. I, fols. 14-18r; Valsaín, 13 de octubre de 1718.

${ }^{10} \mathrm{La}$ media annata se perdonó a todos los primeros alcaldes mayores de Cataluña en atención a ser varas de nueva creación. CERRO NARGÁNEZ, Rafael: «Els alcaldes majors de Catalunya: L'opció civilista enfront de la militarista (1717-1720)» en Butlletí de la Societat Catalana d'Estudis Històrics (Barcelona) 10 (1999), págs. 57-60.

11 En Valencia lo dejó claro el presidente de la Chancillería, Pedro Larreategui y Colón en carta fechada el 6 de octubre de 1707 dirigida al secretario real Juan Milán de Aragón. GARcía MoNERRÍs, Encarnación: La monarquía absoluta y el municipio borbónico: La reorganización de la oligarquía urbana en el ayuntamiento de Valencia (1707-1808), Madrid 1991, pág. 41. Respecto Aragón ver GimÉNEZ LóPEZ, Enrique:«La Nueva Planta de Aragón. Corregimientos y corregidores en el reinado de Felipe V» en Argensola (Huesca) 101 (1988), págs. 20-21. Para Cataluña TORRAS Y RuBE, Josep Maria: Els municipis catalans, págs. 157-158.

Hispania, LXI/1, núm. 207 (2001) 289-314 
el camino quedó abierto, al menos durante las primeras décadas, a los naturales de la Provincia. No obstante, a pesar de la prohibición expresa en los Juicios de Residencia, muchos alcaldes mayores fueron vecinos de la misma población en donde ejercían jurisdicción. Pero como señalaba Lorenzo de Santallana y Bustillo este inconveniente se «disimulaba» ${ }^{12}$.

El perfil profesional que se esperaba de estos sugetos era necesariamente el de un letrado que fuese doctor en derecho civil y canónico, bachiller o licenciado en leyes con el título de abogado de los Reales Consejos ${ }^{13}$. Hay constancia que algunos de los primeros alcaldes mayores catalanes se dedicaban a la abogacía. La mayoría de ellos habían abrazado la causa felipista durante la Guerra de Sucesión española. Aunque no faltaron letrados con un pasado austracista. Desde el año 1714 comenzaron a desempeñar funciones coactivas dentro del aparato represivo impuesto por los Borbones. Esta actividad la realizaron, inicialmente, como asesores del veguer, jueces ordinarios, subdelegados de la Intendencia o auditores de guerra. Luego como alcaldes mayores ${ }^{14}$. Curiosamente su implantación en territorio catalán no fue siempre fácil debido a las prolongadas ausencias de algunos corregidores destinados por Alberoni en la conquista de Cerdeña y Sicilia (1717-1718). Debido a ello la Cámara de Castilla, por Real Orden fechada el 21 de octubre de 1719, autorizó nombrar a la Audiencia cierto número de alcaldes mayores interinos ${ }^{15}$. No obstante siempre hubo excepciones. El primer alcalde mayor catalán fue, curiosamente, un letrado andaluz dependiente de la Real Audiencia valenciana. Nos referimos al granadino Pedro de Saura y Valcarcel, abogado de los Reales Consejos y uno de los pocos tenientes de corregidor de origen castellano de esta época. Saura procedía de Almansa, cuya vara había ejercido en 1707, después de la derrota del Archiduque Carlos. A principios de 1709 (una vez ocupada Tortosa por el duque de Orleans) el corregidor flamenco, caballero de Croix, le nombró su alcalde mayor. Al menos así lo recuerda Melchor de Macanaz en su "Testamento Político"16. En 1714 José Patiño le confió la subdelegación de la Intendencia. Poco después

12 Santayana y Bustillo, Lorenzo de: Gobierno político de los pueblos de España y el corregidor y alcalde y juez en ellos, Madrid 1769 (2. Edición), págs. 299-300.

${ }_{13}$ Los primeros alcaldes mayores catalanes se habían graduado en derecho, durante el reinado de Carlos II, en las universidades forales de Barcelona y Lérida. Suprimidas éstas por Felipe V, el perfíl predominante es el de un bachiller, licenciado o doctor graduado en los centros de: Cervera, Valencia, Orihuela, Gandía, Huesca y Zaragoza. Al menos estas son las universidades que escogían muchos súbditos de la Corona de Aragón y de origen castellano. Estos últimos también habían estudiado sobretodo en Valladolid, Santiago de Compostela, Salamanca y Granada. SARRABLo AGUAREles, Eugenio: Catálogo de consultas del Consejo de Aragón, Madrid 1975, págs. 214 y ss. AHCB: Real Audiencia, vol. 6, fol. 24v; Barcelona, 27 de septiembre de 1742.

${ }^{14}$ Cerro NARgÁNEZ, Rafael:«Els alcaldes majors de Catalunya: entre austriacistes i borbònics (1717-1725)» en Estudis Històrics i Documents dels Arxius de Protocols (Barcelona) 16 (1998), págs. $283-301$

${ }^{15}$ ACA: Real Audiencia, reg. 7, fols. 9-11v; Madrid, 21 de octubre de 1719.

${ }^{16}$ GAY ESCODA, Josep Maria: El corregidor a Catalunya, Madrid 1997, pág. 619.

Hispania, LXI/1, núm. 207 (2001) 289-314 
pasaba a ocupar la vara de Tarragona (1717-1720). Finalizada su estancia en Cataluña se encargó del corregimiento de Barbastro (1721-1724). Mas tarde fue designado teniente de asistente de Sevilla. Pero en 1738 promocionaba a una plaza de alcalde mayor en la Audiencia de Galicia, jubilándose en $1751^{17}$.

Tortosa fue por tanto un caso precoz dentro de las prácticas absolutistas que esperaban imponer los Borbones en Cataluña. Esto explicaría que el resto de alcaldes mayores - todos del país- no llegasen hasta el trienio 1717-1720. Un año después de publicarse el Decreto de Nueva Planta, pero casi al instante en que el Real Decreto de 20 de febrero de 1717 procedía a nombrar corregidores a los gobernadores militares de Gerona, Puigcerdá, Tarragona y Tortosa.

El noble del Principado Francisco de Gayolá, natural de Figueras y subdelegado de la Intendencia (1714), fue designado alcalde mayor de Gerona (1717-1724) por el corregidor, teniente general Tiberio Caraffa. Al igual que su colega en la alcaldía de Besalú, el también subdelegado de la Intendencia Ramón Pastel (1717-1724) ${ }^{18}$. Poco antes le había precedido Juan Bautista Cerdá, asesor letrado del veguer de Puigcerdá (Maguín Saguer), electo por el corregidor, coronel Diego de Villaplana ${ }^{19}$. En 1718 obtuvo el título de regidor de la villa, a pesar de la incompatibilidad de ambos empleos ${ }^{20}$. Por estas mismas fechas el corregidor de Tortosa, Fernando Pinacho, substituía a Pedro de Saura - que marchaba a Tarragona - por el letrado Benito Prima de Viñals (1717-1749), nacido en la villa tortosina de Alcanar ${ }^{21}$. La Real Cédula de 23 de junio de 1718 completó la red de corregidores catalanes, llegando con ella nuevos alcaldes mayores.

El coronel Francisco Antonio Morales, corregidor de Mataró, nombró para la vara de Granollers a Juan Huguet (1718-1731), oficial del Catastro y escribano criminal de la Audiencia desde $1716^{22}$. También era suya la nominación del ciudadano honrado de Barcelona, José Montaner, alcalde mayor de Mataró (1718-1723); amigo íntimo del leridano borbónico José Llopis, luego consejero de Castilla ${ }^{23}$. El mariscal de campo, José Carrillo de Albornoz y Montiel, conde de Montemar, corregidor y gobernador militar de Barcelona, expidió insólitamente desde los campos de batalla de Sicilia, sus dos despachos de alcalde mayor. El primero fue para Oleguer Ametller y Pessió, asesor del veguer de Barcelona (José de Viladomar). El conde de Montemar le nombró su alcalde mayor criminal en $1719^{24}$. Este letrado era desde 1718 regidor vitalicio de Barcelona

\footnotetext{
17 Fernández VegA, Laura: La Real Audiencia de Galicia. Órgano de gobierno en el Antiguo Régimen (1480-1808), La Coruña 1982, vol. 3, pág. 438.

18. ACA: Real Audiencia, reg. 264, fols. 64v-69r; Gerona, 25 de mayo de 1717.

19 ACA: Real Audiencia, reg. 264, fols. 53-54v; Puigcerdá, 17 de abril de 1717.

20 BUB: ms. 1974, «Papeles de Francisco Ametller y José Ametller», fols. 379v-380r.

21 ACA: Cancillería, reg. 6.117, fols. 229-232r; Tortosa, 21 de mayo de 1717.

22 ACA: Cancillería, reg. 6.113, fols. 258v-261r; Barcelona, 17 de septiembre de 1718.

23 Molas Ribalta, Pere: Societat i poder polític a Mataró (1717-1808), Mataró 1973, pág. 81.

${ }^{24}$ ACA: Cancillería, reg. 6.115, fols. 2-3v; Palermo (Sicilia), 26 de septiembre de 1718.
} 
por la clase de nobles. Mérito alcanzado por ser el primogénito de Francisco Ametller, consejero de Castilla ${ }^{25}$. En 1722 Oleguer se jubiló siendo substituido por el tarraconense Ambrosio de Morenés y Mora. Este sugeto era un destacado letrado borbónico, auditor de guerra del marqués de Lede en Cerdeña y Sicilia, que en 1751 ocupó una plaza de oidor en la Audiencia ${ }^{26}$. La alcaldía mayor civil - primera vara de la capital - recayó en el año 1719, en José Francisco de Alós y Rius (1720-1728), asesor general de la Intendencia y auditor de guerra entre sus numerosos empleos ${ }^{27}$. Su padre era José de Alós y Ferrer, acérrimo felipista y oidor de la Real Audiencia. Gracias a sus estrechas relaciones con Patiño y Montemar ascendió a oidor (1733), alcalde de Casa y Corte (1741) y regente de la Audiencia (1742). Finalmente en 1746 obtuvo el título de marqués de Puerto Nuevo ${ }^{28}$.

Los demás nombramientos que siguieron se ajustaron a premisas muy parecidas. En octubre de 1718, el brigadier Melchor Colón de Portugal, corregidor de Vic, cubrió sus respectivas varas con José Baget y Nogués, alcalde mayor de Vic (1718-1719) - luego alcalde mayor de Montblanc (1720) - y Francisco Torrent y Ferrer, subdelegado de la Intendencia y titular de Camprodón (1718$1728)^{29}$. Sin embargo las alcaldías de Lérida, Balaguer y Tárrega, ausentados los corregidores, fueron a partir de 1720 ocupadas interinamente por letrados nombrados directamente por la Real Audiencia. La alcaldía leridana fue concedida a Juan Bautista Bullfarinas (1720-1722), comisario del Real Catastro de Lérida (1715) y subdelegado de la Intendencia ${ }^{30}$. Esta vara puede considerarse una prolongación de la asesoría letrada que desde 1719 ejercía en nombre del teniente de Rey de Lérida, José Lucio de Mexía. La vara de Balaguer fue a manos del caballero Alejandro de Montserrat y Eva — señor de la Tallada-, antiguo austracista que participó en las Cortes del Archiduque Carlos en 1705. Pero poco tiempo estuvo ejerciéndola ya que fue nombrado regidor vitalicio de Lérida ${ }^{31}$. Respecto a la alcaldía de Tárrega, la Real Audiencia se decidió por el asesor del veguer (Jacinto Gomar), es decir José Font (1720-1723), varias veces regidor primero de Tárrega entre 1720-173132. El titular de Villafranca del Penedés fue Alejandro Verdier y Aguilera (1719-1729), hijo del noble del Principado Domin-

${ }^{25}$ MOlas Ribalta, Pere: «Catalans als consells de la monarquia (segles XVII-XVIII)» en Estudis Històrics $i$ Documents dels Arxius de Protocols (Barcelona) 13 (1995), págs. 237-239.

${ }^{26}$ Jordá FernándeZ, Antoni: Poder $i$ comers a la ciutat de Tarragona (S. XVIII), Tarragona 1988, págs. 306-307.

27 ACA: Real Audiencia, reg. 266, fols. 84r-85v; Campo de Rometa (Sicilia), 13 de septiembre de 1719

28 PÉREZ SAMPER, María de los Ángeles: «La familia Alós. Una dinastía catalana al servicio del Estado (siglo XVIII)» en Cuadernos de Investigación Histórica (Madrid) 6 (1982), págs. 195-240.

${ }^{29}$ ACA: Cancillería, reg. 6.113, fols. 276v-283r; Vic, 14/16 de octubre de 1718. Idem, Real Audiencia, reg. 269, fols. 112v-115r; Tarragona, 21 de octubre de 1721 .

30 ACA: Cancillería, reg. 6.119, fols. 1-3r; Barcelona, 30 de abril de 1720.

31 ACA: Real Audiencia, reg. 311, fol. 6v; Barcelona, 11 de octubre de 1720.

32 ACA: Real Audiencia, reg. 266, fols. 143-144r; Barcelona, 1 de abril de 1720. 
go Verdier y Pons, conseller en cap de Barcelona en 1685. Padre e hijo habían asistido a las Cortes de 1705. En el año 1725 Verdier fue sometido - por el alcalde mayor criminal de Barcelona Diego Alba- a una larga investigación acusado de corrupción, pero quedó absuelto ${ }^{33}$. El borbónico Francisco Boleda destacó en la alcaldía igualadina por una importante acumulación de empleos. Además de la vara (1720-1725), fue subdelegado de la Intendencia (1714), asesor general del duque de Cardona (1726) y regidor tercero de Igualada $(1729)^{34}$. Al igual que Boleda, el alcalde mayor de Manresa, el ciudadano honrado de Barcelona Carlos Riu y Rovira, también fue un hábil borbónico que retuvo numerosos oficios. En 1719 Felipe V le nombró uno de los primeros regidores vitalicios de Manresa. Este empleo lo compaginaba desde 1714 con la subdelegación de la Intendencia y con la alcaldía (1720-1733) ${ }^{35}$. Más modesta era la posición del abogado Joaquín Sala, muy ocupado con las dependencias de su juzgado en Berga (1720-1734) ${ }^{36}$. La vara de Agramunt fue a parar a las polémicas manos de Francisco Boxadell, nombrado por el corregidor letrado de Cervera, Francisco Haro y Aguero ${ }^{37}$. Su antiguo austracismo suscitó un rechazo generalizado entre los ministros criminales de la Audiencia, pues su designación, aun confirmada por el Consejo de Castilla, fue siempre calificada de «escandalosa» ${ }^{38}$.

\section{LA ORDENANZA DE INTENDENTES-CORREGIDORES Y SU IMPACTO EN CATA- LUÑA}

Hasta ahora hemos repasado el perfil profesional de los primeros alcaldes mayores nombrados por los corregidores. Esta práctica poco transparente se mantuvo intacta hasta los primeros años del reinado de Fernando VI. Los motivos que provocaron el fin de este procedimiento no parecen estar del todo muy claros. Quizás el temor a la connivencia entre corregidor-alcalde mayor y a las posibles corrupciones derivadas de ella (como la venta de varas), debieron disuadir a la monarquía de suprimir el cordón umbilical que les unía. En Cataluña no hemos encontrado indicios de irregularidades en los nombramientos de alcaldes mayores, pero de existir se debieron de ocultar a ojos extraños ${ }^{39}$. Para luchar contra éste y otros vicios se intenaron arbitrar algunas medidas intimidatorias.

\footnotetext{
33 AHCB: Real Audiencia, vol. 5, fol. 170v; Barcelona, 14 de enero de 1726.

${ }^{34}$ ACA: Cancillería, reg. 6.121, fols. 1-3v; Barcelona, 28 de junio de 1720.

35 BUB: ms. 1974 «Papeles de Francisco Ametller y Josep Ametller» fols. 379-380v. ACA: Cancillería, reg. 6.121, fols. 270r-272v; Barcelona, 2 de septiembre de 1720.

36 ACA: Cancillería, reg. 6.120, fol. 23-25r; Barcelona, 8 de mayo de 1720.

37 ACA: Cancillería, reg. 6.122, fols. 24-27v; Cervera, 23 de mayo de 1720.

38 ACA: Real Audiencia, reg. 135, fol. 253-254v; Barcelona, 5 de diciembre de 1723.

39 Uno de estos extraños casos se produjo en Sevilla. El comprador de la vara fue Pedro Jacome de Linden, obteniendo la aprobación real en despacho firmado en Corella el 8 de septiembre de 
En diciembre de 1715 (un año antes de publicarse el Decreto de Nueva Planta) una representación elevada al rey por el gobernador interino del Consejo de Castilla, Juan Ramírez de Baquedano marqués de Andía, recomendaba combatir la venalidad de alcaldías, sugiriendo que fuese la Cámara quien regulase las designaciones como ya había hecho en 1618 y $1677^{40}$. Pero la oposición del confesor real Guillermo Daubentón impidió que ésta medida se llevase a cabo ${ }^{41}$. Aun así no parece que el memorial de Andía fuese del todo olvidado. Efectivamente, la Ordenanza de Intendentes-Corregidores de 13 de octubre de 1749, en su capítulo segundo, recogía íntegramente las demandas del gobernador del Consejo. A raíz de su publicación los corregidores perdieron definitivamente su capacidad de nombrar alcaldes mayores, pasando su control al libre albedrío del soberano, el cual prevenía que:

«[...]fuesen nombrados por mí a consulta de mi Consejo de la Cámara, que para cada una de dichas tenencias o varas de alcalde mayor, me propondrá tres sugetos hábiles de ciencia y conciencia a fin de que Yo elija de ellas (sino juzgase hacerlo fuera de consulta) al que estimare más útil y conveniente a mi Real Servicio» 42 .

La manera en que afectó la Ordenanza en Cataluña merece una reflexión aparte. Básicamente porque la misma estaba pensada, como su nombre indica$\mathrm{ba}$, para regular la actividad funcional de los intendentes-corregidores. Pero sabido es que en Cataluña la figura del intendente jamás estuvo unida al empleo de corregidor. En la Corona de Aragón Valencia, Zaragoza y Mallorca dispusieron de esta figura dual, pero no así Barcelona ${ }^{43}$. En éste sentido parece claro que la nueva reglamentació había abierto un nuevo camino que determinaría el futuro de la carrera de varas. Pero su puesta en práctica parecía intuir que sólo se limitaría a las varas sujetas a los intendentes-corregidores y no a las de los restantes corregidores. En el caso de Cataluña, la ambigüedad parecía más obvia puesto que - como ya hemos dicho- no existía esta dualidad. Dejando claro que la voluntad regia era desprender a los alcaldes mayores de la nociva tutela del corregidor, recordó en el Decreto de 2 de diciembre de 1749 que lo dispuesto en el capítulo segundo de la Ordenanza debía hacerse extensi-

1711. Tomás Y VALIENTÉ, Francisco:«Ventas de oficios públicos en Castilla durante los siglos XVII y XVIII» en Gobierno e Instituciones en la España del Antiguo Régimen, Madrid 1982, nota. 19, pág. 161. El Decreto de 2 de junio de 1715 prohibía esta venalidad pero reconocía «que los más de los corregidores venden las varas de alcalde mayor con grave perjuicio de la justiciat....);; ver este pasaje en la Novísima Recopilación, Lib. VII, Tit. XI, Ley. XX.

40 Nos referimos a la Pragmática de 10 de octubre de 1618 y a la Real Orden de 28 de octubre de 1677. Álvarez-COCA, Ma Jesús: La Cámara de Castilla. Inventarios de los libros de la Secretaría de Gracia y Justicia que se conservan en el Archivo Histórico Nacional, Madrid 1993, págs. 49-50.

41 GÓMEZ RIVERO, Ricardo: Op. cit., págs. 141-142 y 369-370.

42 Novísima Recopilación, Lib. VII, Tit. XI, Ley. XXIV.

43 EsCARTín SÁNCHEZ, Eduard: La intendencia de Cataluña en el siglo XVIII, Barcelona 1995, págs. 81-84.

Hispania, LXI/1, núm. 207 (2001) 289-314 
ble a todos los corregidores de la monarquía ${ }^{44}$. De todos modos la ejecución de esta orden no fue tan rápida como se hubiese deseado, produciéndose con la novedad cierto retraso y confusión. La Cámara, responsable ahora de todas las designaciones, abrió para las alcaldías, el lento y complejo mecanismo de consultas ya conocido de antaño, que comenzaba con el conocimiento del número vacantes, la selección de memoriales, la elaboración de ternas que luego el Secretario de Estado y del Despacho de Gracia y Justicia, en forma de expediente, despachaba con el rey. Y en fin, la Resolución Real, el juramento ante la Sala Primera de Gobierno del Consejo, licencias, pago de derechos de sello y media annata.

Sin embargo es justo señalar que, en Cataluña, parte del retraso sufrido por la Cámara en la elaboración de sus ternas, se debió a la necesidad que sus actuales propietarios finalizasen sus respectivos trienios ${ }^{45^{\prime}}$. Aunque hubo algunas excepciones motivadas por fallecimientos repentinos. En febrero de 1750 , el alcalde mayor civil de Barcelona, el ciudadano honrado de Barcelona, Manuel Pastor de Sentís y Ferrer, causaba baja por este motivo ${ }^{46}$. La Consulta de la Cámara, fechada el 27 de abril, fue en este caso diligente. Pero la Resolución Real de junio de 1750 resolvió cubrir la vacante promocionando a su compañero de la vara criminal - Manuel Delás y Casanovas - a la civil, después de haberla ejercido durante doce años ${ }^{47}$. Automáticamente la alcaldía mayor criminal fue consultada el 29 de julio del mismo año, acabando con el nombramiento del caballero Jacinto Tudó y Alemany, hijo de Juan Tudó Romanya, señor de Villa Ardida ${ }^{48}$ : En 1758 substituyó a Manuel Delás en la tenencia civil. Pero cuatro años más tarde promocionaba, consecutivamente, a una plaza de alcalde del crimen y de oidor en la Real Audiencia. En 1766 Tudó se convirtió en el único alcalde mayor catalán del siglo XVIII que ascendía a una plaza de consejero de Castilla ${ }^{49}$. Otra consulta se sustanció a finales de 1750. Esta vez el fallecido fue el alcalde mayor de Tortosa, Benito Prima y Viñals, que ejerció la vara durante más de tres décadas. Caso insólito en una alcaldía catalana. Su reemplazo fue Pedro Tomás Alcoba $(1751-1755)^{50}$. Este letrado castellano puso fin al monopolio ejercido por letrados catalanes en Tortosa.

\footnotetext{
${ }^{44}$ GonZÁlez Alonso, Benjamín: Op. cit., nota. 135, pág. 267.

${ }^{45}$ Mercader, Joan: Op. cit., pág. 320-321.

46 Cerro Nargánez, Rafael:«Barcelona y sus alcaldes mayores: perfil sociológico de una élite letrada al servicio de los Borbones (1718-1750)» en Pedralbes (Barcelona) 17 (1997), págs. 217-238.

47 AHCB: Registro de Despachos, vol. III, fols. 40v-44r; Buen Retiro, 9 de julio de 1750.

48 AHCB: Registro de Despachos, vol. III, fols. 44r-47v; San Lorenzo, 8 de septiembre de 1750.

49 FAYARD, Janine:«Los ministros del Consejo Real de Castilla (1746-1788)» en Cuadernos de Investigación Histórica (Madrid) 6 (1982), pág. 135. Tudó ingresó en el Consejo de Castilla por Decreto de 7 de agosto de 1766. También fue. asesor del tribunal de la Reales Guardias y asesor del Consejo de Guerra. ANDújar CaStillo, Francisco: Consejo y consejeros de Guerra en el siglo XVIII, Granada 1996, págs. 274-275.

so ACA: Real Audiencia, reg. 494, fols. 147r-150r; Buen Retiro, 20 de enero de 1751.
}

Hispania, LXI/1, núm. 207 (2001) 289-314 
El año 1751 trajo consigo un rosario de nuevas consultas para proveer las ya perceptibles vacantes de ocho alcaldías. Sus nuevos titulares eran mayoritariamente de origen foráneo. El primero en llegar fue el valenciano José Alegret, abogado de los Reales Consejos, que ocupó la vara de Mataró entre 1751 y 1756 , tras ejercer la vara de San Felipe $(1738-1748)^{51}$. Substituía al veterano Antonio Espona, nombrado regidor de Mataró (1752). En 1757 Alegret abandonó Mataró para hacerse cargo de la vara de Tarragona, pero renunció a ella antes de tomar posesión. El andaluz Francisco Chaves de Córdoba, también abogado de los Reales Consejos, fue nombrado alcalde mayor de Gerona a mediados de $1751^{52}$. Su padre, Andrés Chaves, fue secretario del Virrey de Navarra. Tíos suyos eran el teniente coronel Juan de Chaves y el teniente de Rey de Gaeta, Miguel Chaves, preso por los imperiales en 1712. En cualquier caso Chaves de Córdoba era un letrado de amplia experiencia profesional. Había sido corregidor de Olmedo (1735), Agreda (1741) y Orense (1746). Después de obtener varias prórrogas en Gerona renunció a una plaza vacante en Lérida, pero aceptó la alcaldía criminal de Barcelona en $1762^{53}$. Posiblemente nos encontramos ante un letrado arraigado en Cataluña ya que rechazó trasladarse a Granada para quedarse en el país. Ejerció también la vara de Mataró (17721776) y de nuevo la de Gerona (1777-1780). El catalán Ramón de Eva y Betlloc estaba emparentado con los nobles del Principado, José y Antonio de Eva y Betlloc, asistentes a las Cortes de $1705^{54}$. Esto no fue obstáculo para que iniciara una larga carrera que le llevó en 1751 a comenzar su trienio en Besalú y a finalizarlo en Vic por Real Cédula de 24 de noviembre de $1757^{55}$. Años antes, en 1741, el corregidor de Gerona, el teniente coronel José Fernando de Córdoba Alagón, le había nombrado su teniente letrado ${ }^{56}$. Excelentes debieron de ser sus méritos ya que después de una fructífera estancia en la vara criminal de Barcelona (1758-1762), finalizó sus días en la bien dotada alcaldía gaditana (1767). El doctor en derecho, Luís Vidal de Lorca, hijo de Francisco Pérez de Lorca, teniente coronel del regimiento de Santiago, fue titular de la vara leridana entre 1751 y $1755^{57}$. Este letrado también tenía una amplia experiencia en la carrera judicial. La inició en la alcaldía de Villafranca del Penedés el año

51 IRLES VICENTE, María del Carmen: Los municipios de realengo valencianos durante el siglo XVIII, 1708-1808. Las sedes corregimentales, Universidad de Alicante (tesis doctoral) 1994, vol. 2, pág. 901.

52 ACA: Real Audiencia, reg. 494, fols. 243v-245r; Buen Retiro, 14 de septiembre de 1751.

53 FLUVIÁ EsCORSA, Armand de: «Índice de los cargos y empleos del antiguo ayuntamiento de Barcelona» en Documentos y Estudios (Barcelona) 13 (1964), pág. 215.

${ }^{54}$ BRU De SAla, Luís y Fluví́ EsCorsa, Armand de: Nobiliari del reial cos de la noblesa de Catalunya, Barcelona 1998, pág. 73.

ss ACA: Real Audiencia, reg. 494, fols. 239r-242v; Buen Retiro, 14 de septiembre de 1751. Ibidem., reg. 501, fols. 9v-10r; Buen Retiro, 24 de noviembre de 1757.

56 ACA: Real Audiencia, reg. 219, fols. 1-4v; Gerona, 30 de octubre de 1741.

57 ACA: Real Audiencia, reg. 494, fols. 147r-150v; Aranjuez, 6 de mayo de 1751. LladonosA I PuJoL, Josep: Història de Lleida, Tárrega 1974, vol. 2, pág. 629.

Hispania, LXI/1, núm. 207 (2001) 289-314 
1743. Pero en esta vara fue acusado de abuso de autoridad. Prosiguió después en la alcaldía de Mataró (1756-1761), para continuar luego de corregidor en Ponferrada (1764): Menos importante resulta el curriculum del alcalde mayor de Tarragona, Juan Francisco Sarrá (1751-1757), que si bien en 1750 había ejercido interinamente la vara por ascenso de Ramón de Ferrán y Biosca a una plaza de alcalde del crimen de la Audiencia (1749), no fue consultado tras su cese para ningún otro empleo ${ }^{58}$. También estos eran los casos de Vicente Albelda, alcalde mayor de Igualada (1751-1755) y Leonardo Aznau de Marrón y Doncell, alcalde mayor de Berga (1752-1755). En cambio mejor fortuna tuvo el alcalde mayor de Manresa, José Ferrer de la Puente (1751-1752) antiguo alcalde mayor de Alicante (1749-1750), que después de un año en la vara pasó a la Auditoría de Guerra de Venezuela y después a diferentes plazas de oidor en Audiencias americanas, como la de Quito (1764-1778) y la de Lima (17781782). En 1783 culminó su carrera siendo nombrado regente de la Audiencia de Santa Fe de Bogotás9. El valenciano José Ferrer fue substituido en esta alcaldía por Francisco Tarragona y Finestres (1752-1757)60. Este ciudadano honrado y abogado de los Reales Consejos había sido alcalde mayor de Agramunt en 1725 y de su Igualada natal (1742). En el año 1753 el rey le nombró regidor de Manresa, compaginando este empleo con la vara de alcalde mayor ${ }^{61}$. El resto de alcaldías: Granollers, Vic, Camprodón, Puigcerdá, Balaguer, Tárrega, Montblanc, Villafranca del Penedés y Agramunt, fueron todas consultadas por la Cámara el día 23 de marzo de 1752, resolviéndose sus nombramientos pocos meses después. Cabría citar algunos individuos de esta nómina como el barcelonés José Oliver, alcalde mayor de Vic (1752-1757). Este letrado procedía de las varas de Tárrega (1724-1727) y Camprodón (1728-1752)62. En esta última fue substituido por Domingo Capdevila de Montaner (1752-1762), alcalde mayor de Puigcerdá en el año 1745. Un hermano suyo el doctor en derecho, Gerónimo Esteban Oiver, fue alcalde mayor de Montblanc (17321745) y un sobrino, Ignacio Francisco Oliver y de Peyre, doctor en derecho por la Universidad de Cervera, ocupó diversas alcaldías catalanas en la segunda mitad de la centuria. Más interesante era el expediente de méritos de Ignacio Castells y Casanovas, alcalde mayor de Montblanc (1752-1756) ${ }^{63}$. En el año 1741 el coronel Fernando de Guzmán Porcel, corregidor de Manresa, le nom-

\footnotetext{
58 ACA: Real Audiencia, reg. 494, fols. 213v-215r; Buen Retiro, 8 de julio de 1751.

59 BURKhOlder, Mark. A y CHANDLER, D. S: De la impotencia a la autoridad: la corona española y las Audiencias en América, 1687-1808, México 1984, págs. 358, 416 y 422.

60 ACA: Real Audiencia, reg. 495, fols. 264-265r; Buen Retiro, 19 de septiembre 1752.

${ }^{61}$ ACA: Cancillería, reg. 6.146, fols. 172v-174r; Ciudad de Armedo, 14 de septiembre de 1725. Id., Real Audiencia, reg. 219, fols. 175-177v; Villafranca del Penedés, 5 de agosto de 1742. Ibidem., reg. 496, fols. 222-224v; Buen Retiro, 2 de septiembre de 1753.

62 PLANES I ClOSA, Josep Maria: «Radiografia d'un municipi borbònic català: persones i grups socials al poder a Tàrrega», en Pedralbes (Barcelona) 6 (1986), pág. 120.

${ }^{63}$ ACA: Real Audiencia, reg. 495, fols. 201-204v; Aranjuez, 31 de mayo de 1752.
} 
bró su alcalde mayor ${ }^{64}$. Sin embargo en el año 1757 obtuvo el título de corregidor interino por el fallecimiento del mismo Guzmán ${ }^{65}$. Después pasó a la alcaldía de Igualada (1763-1764) y luego a la de Lérida (1764-1767). En 1773 - acabado su segundo trienio en la vara criminal de Barcelona - fue ascendido a alcalde del crimen de la Audiencia de Cataluña y en el año 1783 promocionó a oidor ${ }^{66}$. El letrado aragonés, Ignacio Farraz, fue destinado a la alcaldía de Agramunt después de ejercer veinte años la vara de Granollers (1732-1752). No debió motivarle este destino, pues renunció a él para ser nombrado alcalde del crimen en $1760^{67}$.

\section{LAS CONTRADICCIONES DE UNA CARRERA EN TRANSICIÓN (1750-1783)}

Estos casos de promoción a tribunales superiores que hemos documentado hasta mediados del siglo XVIII, pueden considerarse particularmente excepcionales, explicables en parte, por méritos de fidelidad contraídos por estos letrados durante el conflicto dinástico. Así se pueden entender los ascensos relevantes del caballero Ramón de Ferrán y Biosca, alcalde mayor de Tarragona (1726-1749) y de José Francisco de Alós y Rius, Ambrosio de Morenés y Mora o de Jacinto Tudó Alemany; los tres últimos alcaldes mayores de varas tan importantes como las de Barcelona. Estas varas fueron también ocupadas por dos afortunados letrados aragoneses: Miguel Gómez y José Moya. El primero era regidor perpetuo y alcalde mayor civil y criminal de Zaragoza (17521762). Pasó brevemente por la alcaldía de Barcelona (1767) para ser ascendido a alcalde del crimen y oidor de la Audiencia de Aragón (1768). Dos años después ocupaba una plaza de alcalde de Casa y Corte ${ }^{68}$. José Moya era muy diferente a su paisano. Este hijo de Torrellas y abogado de los Reales Consejos, tenía una dilatada experiencia judicial. Había sido corregidor de Ávila (1755) y Segovia (1761). Además había ejercido diversas alcaldías que le llevaron a las varas de Badajoz, Burgos y Cartagena. En 1773 fue nombrado alcalde mayor de Barcelona ${ }^{69}$. Finalizado su trienio en el corregimiento de Mancha Real, aceptó servir en las colonias americanas. En 1779 fue nombrado ministro de la Real Audiencia de Guatemala (Nueva Galicia) y al poco tiempo oidor en la Audiencia de Méjico en Nueva España $(1787)^{70}$. Pero excepciones aparte, era evidente

\footnotetext{
${ }^{64}$ ACA: Real Audiencia, reg. 219, fols. 12r-15v; Manresa, 20 de junio de 1741.

65 ACA: Real Audiencia, reg. 500, fols. 198-200v; Madrid, 19 de julio de 1757.

66 Molas Ribalta, Pere:«Las Audiencias borbònicas en la Corona de Aragón» en Historia Social de la Administración Española. Estudios sobre los siglos XVII y XVIII, Barcelona, 1980, págs. 154-155.

${ }^{67}$ ACA: Real Audiencia, reg. 212; fols. 90-95v; Mataró, 30 de octubre de 1731. MOLAS RIBALTA,Pere: $O p$. cit., pág. 155.

${ }^{68}$ Molas Ribalta, Pere: Op. cit., págs. 149 y 151.

69 ACA: Real Audiencia, reg. 888, fols. 63v-66r; San Ildefonso, 20 de febrero de 1773.

70 Burkholder, Mark. A y ChAndler, D.S: Op. cit..págs. 338 y 392.
} 
que esta política de promociones no se generalizaba entre los alcaldes mayores de Cataluña. La Ordenanza del año 1749 ofrecía cierta garantía de continuidad y movilidad, pero dejaba sin regular «algunas salidas proporcionadas a su carrera». Las plazas eran limitadas y los candidatos consultados numerosos. Con todo, si complicado era entrar en la carrera de varas más difícil era aun salir de ella ascendido. Por si fuera poco las consultas de la Cámara pusieron fin al monopolio ejercido hasta ahora por letrados catalanes, siendo desplazados, en muchos casos, por colegas de otras Provincias: Aunque también, no lo podemos negar, la Ordenanza abrió las puertas a letrados catalanes en tenencias de otros lugares. De todos modos uno de los graves defectos que convertían este empleo en Cataluña en poco atractivo era su escasa remuneración. Según la Real Cédula de 23 de junio de 1718, el salario de un alcalde mayor era de 300 escudos anuales, excepto la vara criminal de Barcelona que tenía 500 escudos $^{71}$. Estas cantidades permanecieron sin cambios durante largo tiempo. Pero una Real Orden del marqués de Esquilace, fechada el 11 de marzo de 1763, rompió con esta tónica aumentando hasta 6.000 reales el sueldo del alcalde mayor de Gerona. Sin embargo este aumento fue desigual y discriminatorio. Un ejemplo, en 1779 podemos encontrar cuatro niveles diferentes de salarios que oscilaban entre los 3.000 reales anuales de las varas de Igualada y Agramunt; los 5.378 de Vic y Villafranca del Penedés o los 6.000 reales de Gerona y Mataró ${ }^{72}$. Todas las demás alcaldías rondaban emolumentos parecidos. En Barcelona, dos Reales Decretos expedidos por el Consejo de Castilla, el 20 de noviembre de 1763 y el 10 de marzo de 1764 , consiguieron equiparar sus juzgados (civil y criminal) y salarios $^{73}$. Ahora sus dos varas estaban valoradas en 4.400 reales pagados por la ciudad y 5.000 reales satisfechos, desde 1750 , por la Real Tesorería. Sin embargo, si hacemos caso a la representación elevada al rey, en 1776, por los alcaldes mayores, Pedro Agustín Mendieta y Fulgencio Antonio Molina, cada vara debería de haberse tasado en 20.000 reales anuales, pero según ellos «sin duda se hizo en otro tiempo en la actual constitución es absolutamente incierta (...) reduciéndose el todo a 13.000 reales escasos» ${ }^{74}$. Esto quería decir que las mejores tenencias catalanas estaban por entonces devaluadas. Después de muchas décadas sin incrementos salariales, era evidente que nuestros alcaldes mayores habían perdido poder adquisitivo y que los tímidos aumentos registrados ya no se ajustaban a las condiciones de vida necesarias para la supervivencia de un letrado empleado en Cataluña; Provincia que además percibía como ninguna el desfase

${ }^{71}$ Los alcaldes mayores cobraban su salario en cuatro tercias trimestrales por la vía del reparto entre los vecinos del corregimiento. Sólo los de Barcelona obtenían sus emolumentos de los propios de la ciudad, a través de un Real Cédula de Dotación concedida por Felipe V. ACA: Real Audiencia, reg. 6, fols. 118-121v; Valsaín, 23 de junio de 1718.

72 ACA: Real Audiencia, reg. 895, fols. 236-239r; San Ildefonso, 22 de agosto de 1779.

73 Novísima Recopilación, Lib. VII, Tit. XI, Ley. XXV.

74 ACA: Real Audiencia, reg. 574, fols. 364r-365v; Barcelona, 4 de diciembre de 1776. 
producido entre precios y salarios ${ }^{75}$. En el año 1764 una representación de trece alcaldes mayores encabezados por José Rebull, alcalde mayor de Tortosa y Luís Gorrón Contreras, titular de Balaguer, solicitaron al monarca un aumento generalizado de 6.000 reales anuales por estos motivos ${ }^{76}$. Un año después la Real Audiencia respaldaba esta petición por considerar cierto que:

«[...]de algunos años a ésta parte han tomado tan crecido aumento los comestibles y géneros de calzar y vestir y aun los alquileres de casas que se paga el doble precio de lo que antes»77.

A partir de la segunda mitad de la centuria, Cataluña se había convertido en un destino muy caro para los alcaldes mayores. Más gravoso si cabe para los de origen foráneo. En 1787 Nicolás Campaner Sastre, abogado del Colegio de Madrid y alcalde mayor de Tortosa, aseguraba que el alquiler de su casa no bajaba de 700 a 800 reales anuales y que los gastos de comida y vestuario para su esposa e hijos ascendían a 1.800 reales. Aparte el salario que destinaba a su agente en Madrid ${ }^{78}$. Todo ello sin deducir gastos como la media annata y el Monte Pío. Por su parte Antonio Argentí y Leis, abogado de los Reales Consejos y alcalde mayor de Vic, pagaba un alquiler de 900 reales, lo que con su sueldo le daba «imposibilidad de poder mantenerse con su familia que se compone de seis personas" 79 .

Tres fueron las propuestas defendidas por los alcaldes mayores —ante el Consejo de Castilla - para incrementar sus respectivos salarios: el reparto, los propios y arbitrios y la Real Tesorería ${ }^{80}$. La Real Audiencia siempre se opuso a las dos primeras opciones porque el reparto incrementaría la presión fiscal sobre el vecindario. La segunda porque contaba con la oposición de los ayuntamientos, ya que todos sus propios estaban consignados «al pago de acreedores censalistas y extinción de vales reales». La tercera salida parecía más viable, pero la Real Tesorería estaba controlada por el intendente que además pagaba a los oficiales de sus tribunales y a las tropas del rey ${ }^{81}$. Este ministro muchas veces se resistió en asumir más compromisos salariales. Quedaba otra posibilidad. Incrementar el producto de poyo y juzgado. Es decir las costas procesales y los derechos de la Curia tanto en las causas civiles como criminales. Sin embargo el Real Arancel de justicia fechado en el año 1734 «expresaba que los tenientes de Barcelona, a cuio modelo se goviernan los demás alcaldes del Principado, ningunos dere-

75 VILAR, Pierre: «Transformaciones económicas, impulso urbano y movimiento de los salarios: la Barcelona del siglo XVIII» en Crecimiento y desarrollo. Economía e historia. Reflexiones sobre el caso español, Barcelona 1964, págs. 194-233.

76 ACA: Real Audiencia, reg. 559, fols. 12v-15r; Madrid, 22 de febrero de 1764.

77 ACA: Real Audiencia, reg. 805, fols. 123v-124r; Barcelona, 29 de marzo de 1765.

78 ACA: Real Audiencia, reg. 586, fols. 323-326v; Tortosa, 14 de julio de 1787.

79 ACA: Real Audiencia, reg. 1.021, fols. 518-519r; Madrid, 13 de julio de 1804.

80 ACA: Real Audiencia, reg. 805, fols. 124-127v; Barcelona, 29 de marzo de 1765.

81 ESCARTín SÁNCHEZ, Eduard: Op. cit., págs. 129-133. 
chos perciban en las causas criminales» ${ }^{82}$. Era muy fácil intuir que el problema salarial no tenía tampoco fácil solución, porque la vigencia del derecho civil catalán imponía ciertas restricciones en la práctica judicial, que difería de la de otros lugares de España. Como así lo reconocía Fulgencio Antonio Molina en 1779.

«Teniendo así mismo presente que los alcaldes mayores que vienen a este destino y no son hijos de la Provincia han de hacer particular estudio para entender el idioma y las Constituciones que rigen así en lo civil como en lo criminal» ${ }^{83}$.

También la compleja superposición de jurisdicciones, propia del Antiguo Régimen, era nefasta para el producto de poyo y juzgado de estos letrados, que desde sus Curias observaban, con impotencia, limitaciones judiciales a su actuación impuestas por la presencia de otros tribunales reales con capacidad procesal en primera instancia. No olvidando los diferentes tribunales de los bailes, barones y eclesiásticos que también rivalizaban en los pleitos con el alcalde mayor. Así se quejaba amargamente Manuel Noreña, titular de Mataró, que con 7.000 vecinos:

«Muchos son matriculados en la Marina otros del comercio y otros dependientes de diferentes ramos de rentas y todos sugetos a sus respectivos tribunales y aunque los comerciantes no siendo en casos de Lonja de Mar, están sugetos a la justicia ordinaria, esto no obstante como la mejor parte del pueblo esta dedicado a dicha negociación, viene a quedar este juzgado con jurisdicción mui limitada en el caso del vecindario, dentro de cuyo término que es bien corto tiene sólo jurisdicción con el corregidor» $\$ 4$.

Para los alcaldes mayores de Barcelona, sede de importantes tribunales, el culpable de su menguante salario en costas procesales era:

«El establecimiento de Quarteles y Juzgados de Provincia en que entienden en todo género de causas los cinco alcaldes del crimen de esta Real Audiencia de forma que los alcaldes mayores que siempre fueron dos en Barcelona y que aun así sólo conseguían el mantenerse con una moderada decencia, oy son siete» ${ }^{85}$.

No obstante para la mayoría de alcaldes mayores, todos estos problemas se debían a la prepotencia de la Real Audiencia que:

«[...]regularmente por qualquier pretesto inhibe del conocimiento al [juez] inferior antes de que el caso llege de dar su sustancia definitiva y principalmente si el interés de que se trata en el proceso es mayor de 1.000 libras» 86 .

82 ACA: Real Audiencia, reg. 1.014, fol. 312, Madrid, mayo de 1797.

83 ACA: Real Audiencia, reg. 576, fols. 328-329v; Barcelona, 22 de octubre de 1779.

84 ACA: Real Audiencia, reg. 572, fols. 75-78v; Mataró, 1 de abril de 1776.

85 ACA: Real Audiencia, reg. 574, fols. 365-368v; Barcelona, 4 de diciembre de 1776.

86 ACA: Real Audiencia, reg. 1.009, fols. 5-9r; Madrid, 13 de enero de 1792.

Hispania, LXI/1, núm. 207 (2001) 289-314 
Este tribunal también tenía sus propios proyectos respecto a los alcaldes mayores de Cataluña. Respondiendo a una Carta Acordada remitida por el fiscal Campomanes, en abril de 1770, la Audiencia sugería reducir los corregimientos de Cervera, Talarn, Vic, Mataró, Villafranca del Penedés, Manresa y Puigcerdá a corregimientos de letras ya que todos ellos carecían, en ese mismo momento, de guarnición militar. Es decir la Real Audiencia estaba meditando en el establecimiento de un corregidor de letras mejor remunerado que un alcalde mayor pero memos costoso que un corregidor militar ${ }^{87}$. Sin embargo este proyecto conllevaba ciertos sacrificios, comprensibles, como la supresión inevitable de los alcaldes mayores en estas cabezas de partido. Deseo que por cierto acariciaban los regidores de Igualada desde hacía tiempo a tenor de la fuerte rivalidad existente entre el alcalde mayor y su propio baile, el cual representaba los intereses de una villa que compartía la jurisdicción ordinaria con el rey ${ }^{88}$. Esta opinión se expuso también con claridad en una representación realizada por los diputados del común y sindico personero de Puigcerdá, partidarios también de adoptar esta medida draconiana:

"Considerando la Audiencia fundada la instancia de los suplicantes es de parecer que sería de la Real Clemencia de V.Mgt, el que se digne mandar suprimir las plazas de gobernador y theniente de corregidor de aquella villa, estableciendo un corregidor de letras como así lo informó la Audiencia a V. Mgt, en Consulta de 26 de mayo de 1770 que dirigió al Consejo de la Cámara» 89.

Sólo el fracaso de los proyectos civilistas y la combativa oposición militarista parecen explicar la resistencia de Carlos III por tocar la planta militar del país creada por su padre, considerando con ello que la presencia de corregidores militares era lo que justificaba la existencia de alcaldes mayores como auxiliares letrados en materia de justicia ${ }^{90}$. En definitiva, nos encontramos ante un círculo vicioso de circunstancias e intereses creados muy difícil de romper ya que el alcalde mayor fue siempre considerado un eslabón poco importante, sacrificable dentro del complejo escalafón de la administración borbónica en Cataluña.

\footnotetext{
87 ACA: Real Audiencia, reg. 810, fols. 154-158r; Barcelona, 26 de mayo de 1770.

88 TORRAS I RiBE, Josep Maria: UUn plet jurisdiccional a les darreries de l'Antic Règim» en Miscellanea Aqualatensia/2 (Igualada) 7 (1974), págs. 117-134.

89 ACA: Real Audiencia, reg. 811, fols. 54-55v; Barcelona, 30 de abril de 1771.

${ }^{90}$ Que los corregimientos de letras implicaban la extinción de la vara de alcalde mayor se puede ver en Valencia. Onteniente fue corregimiento de letras sin alcalde mayor y Alcoy lo mismo desde 1747. En Jijona en el año 1753 cesaron el corregidor militar coronel Pedro Corbi y su alcalde mayor, Juan Bautista Ruiz Delgado, para convertirse éste último en corregidor letrado. Alcira fue corregimiento de letras entre 1768-1792. Su primer corregidor de letras fue Francisco Verdún Espinosa (1768-1772) que substituía al teniente coronel Juan José Sada y al alcalde mayor Luís Borrás y Goya. Apartir de 1792 Alcira recuperaba su corregidor militar -coronel Antonio Alcedo- y su alcalde mayor, Dionisio Catalán. GIMÉNEZ LÓPEZ, Enrique: Militares en Valencia 1707-1808, Alicante 1990, págs. 141-158.
} 


\section{UN PASO HACIA LA PROFESIONALIZACIÓN: EL DECRETO DE 1783}

En este marco de angustiosa frustración y descontento hay que contextualizar el fundamental Decreto de 29 de marzo de 1783, derivado en la Real Cédula de 21 de abril ${ }^{91}$. A nosotros nos interesan algunas de las particularidades del Decreto que afectan a la realidad cotidiana de las alcaldías catalanas, cuyos rasgos más sobresalientes son su clasificación en tres escalas: una de entrada, otra de ascenso y la última de término. En esta linea diremos que sólo la vara civil o más antigua de Barcelona se erigía como la única de tercera clase. La criminal o más moderna así como las alcaldías de Gerona, Lérida, Tarragona, Mataró y Tortosa, se convertían en plazas de segunda clase. Mientras que las restantes trece varas pasaban a ser de primera clase ${ }^{92}$.

Resulta interesante el procedimiento accidental utilizado por Carlos III para nombrar los primeros alcaldes mayores de 1783, ya que éste difiere del practicado en 1750 . Efectivamente, informado el rey del excesivo número de varas catalanas vacantes, decidió eludir los habituales mecanismos de consulta de la Cámara por considerarlos dilatorios resolviendo, por Real Decreto de 1 de octubre de 1783, designar a los titulares de: Agramunt, Balaguer, Besalú, Lérida, Mataró, Montblanc, Puigcerdá, Tárrega, Vic, Granollers, Igualada y las dos tenencias de Barcelona ${ }^{93}$. Es decir Carlos III decretó proveer simultáneamente trece varas de alcalde mayor (la mitad de las existentes), en una proporción tan elevada y en tan corto espacio de tiempo que jamás se había dado en Cataluña durante el siglo XVIII. La decisión de dejar al margen de los nombramientos a la Cámara de Castilla parece que se tomó a instancias de Floridablanca. Pero debió de ser un caso circunstancial motivado por el gran número de vacantes producido, ya que las restantes plazas (Gerona, Camprodón y Tortosa) fueron consultadas por la vía ordinaria de la Cámara durante el bienio 1784-1785. En cambio se mantuvieron en sus puestos los alcaldes mayores de Tarragona - Bartolomé Estada (1782-1787)_, Villafranca del Penedés - Miguel Llorca Agulló (17821786) —, Manresa - Antonio Sala y Torres de Bages (1782-1786)_, y de Berga —Pedro Manuel Lazcano (1782-1786) - . Todos ellos nombrados antes de' 1783.

\footnotetext{
${ }^{91}$ Novísima Recopilación, Lib. VII, Tit. XI, Ley. XXIX.

92 GAY EsCODA, Josep Maria: Op. cit., págs. 1.016-1017.

93 Sus nombres eran: Agramunt: Alfonso Valenzuela y Covadela (1784-1790); Balaguer: Ramón Texidor (1784-1790); Besalú: Antonio Quer y Villaró (1784-1790); Lérida: Buenaventura Claris y Postius (renunció); Mataró: Antonio Alcaide (1784-1791); Montblanc: Santiago Nuñez Casqueiro de Santa Maria (1784-1790); Puigcerdá: Nicolás María Estevan (1784-1790); Tárrega: Mariano Berga y Felip (1784); Vic: Francisco Carballo Ledesma (1784-1790); Granollers: Mariano Vilellas de Mola (1784-1790); Igualada: Joaquín Gálvez y Santillana (1784-1790); Barcelona: Pedro Andrés Díaz Sánchez (renunció) y Andrés Ciria (1784-1788). GÓMEZ RIVERO, Ricardo: Op. cit., pág. 164.
}

Hispania, LXI/1, núm. 207 (2001) 289-314 
Aparentemente la letra de este Decreto estaba fuertemente motivado por el espíritu reformista carolino ${ }^{94}$. Las expectativas levantadas y las esperanzas despertadas fueron muchas. La legislación daba un paso más en la profesionalización de la carrera equiparando al alcalde mayor con el corregidor letrado, como confirmaba que «todo lo dicho en los precedentes capítulos debe entenderse proporcionalmente con los alcaldes mayores» ${ }^{95}$. Pero si bien es cierto que esta equivalencia podía materializarse en Castilla, Aragón y Valencia, no se podía hacer de igual manera en Cataluña, en donde no existían corregimientos de letras y el único que había disfrutado de esta distinción (Cervera) estaba ahora en manos militares. Muy pronto se fue imponiendo la cruda realidad. Consiguientemente aparecieron las primeras limitaciones que ni siquiera la Instrucción de mayo de 1788 o la Real Cédula fechada el 7 de noviembre de 1799 pudieron corregir. En teoría para llegar a la clase superior señalada por el Decreto de 1783 había que cumplir sucesivamente un sexenio en las otras dos categorías inferiores. Pero el exceso de aspirantes y el corto número de plazas hacía casi imposible el cumplimiento de estos plazos, lo que obligaba a prolongadas y erráticas estancias en una misma categoría ${ }^{96}$. Consideremos también que todas las varas, catalanas, independientemente de las sugerencias realizadas de mejora salarial oscilaban, según la Cámara de Castilla, entre los 5.000 y los 9.000 reales anuales (incluyendo los emolumentos de juzgado) y que por lo tanto ninguna de ellas alcanzaba los 11.000 reales propios de una alcaldía de entrada. Por entonces las dos varas más importantes de Cataluña - las de Barcelona- ya hemos visto que estaban valoradas en 13.387 reales, es decir el equivalente a una plaza de segunda clase. Esto quería decir que no existía ninguna vara que superase en Cataluña los 22.000 reales propios de una tercera clase y que el Decreto ignoraba, deliberadamente, la realidad salarial de la alcaldías del país, clasificándolas en una categoría ficticia, muy por encima de su verdadera dotación ${ }^{97}$. Que nosotros sepamos, Pedro José Menduíña, alcalde mayor de CamprodónOlot, en 1802, y Antonio Argentí y Leis, alcalde mayor de Vic en 1805, fueron los únicos letrados que recibieron, excepcionalmente, los 11.000 reales conforme a su clase ${ }^{98}$. Las demás solicitudes fueron rechazadas o bien se dilataron. Consecuentemente se volvieron a reproducir los mismos problemas de antes. En 1795 el alcalde mayor de Manresa, Antonio Grijalba, solicitaba aumento de sueldo "porque ban subido los precios de los comestibles en este país a tanto que superan

${ }^{44}$ GAY ESCODA, Josep Maria: «Corregiments militars catalans: el miratge de lesreformes carolines» en Segon Congrés d'Història Moderna de Catalunya, Pedralbes (Barcelona) 8-II (1988), págs. 87-105.

9s GONZÁlez Alonso, Benjamín: Op. cit., págs. 266-269.

96 ROLDÁN Verdejo, Roberto: Los jueces de la monarquía absoluta, Santa Cruz de Tenerife 1989, págs. 207-213.

97 GAY ESCODA, Josep Maria: El corregidor a Catalunya, págs. 492-493.

98 ACA: Real Audiencia, reg. 1.019, fols. 518r-520v; Madrid, 31 de octubre de 1802. Ibid., reg. 1.022, fols. 545-547r; Madrid, 21 de noviembre de 1805. 
a un duplicado del que tienen en Madrid» ${ }^{99}$. Incluso en una fecha tan lejana como junio de 1812, en plena Guerra de la Independencia, la Regencia del Reino remitía a la Audiencia una representación de Gabriel Hernández, alcalde mayor de Villafranca del Penedés, Juan Esteban Anglada de Igualada y Matías Mestre, titular de la vara de Montblanc, solicitando los 11.000 reales de su clase como les señalaba el Decreto del año 1783 «en atención a habérseles aumentado considerablemente su trabajo con la agregación de tantos pueblos de señorío a sus respectivas jurisdicciones y no tener con que vivir» ${ }^{100}$. Cataluña decididamente no era uno de los destinos más deseados. A pesar de la preferencia encubierta por parte de la Cámara de letrados ajenos al país, muchos seguían teniendo problemas de integración que se traducían en el desconocimiento de la cultura y el derecho civil catalán. La distancia, el corto salario y el elebado nivel de vida eran también motivos de contenido descontento. Aunque este problema también lo padecían los nativos. Un ejemplo estadístico. De los 209 alcaldes mayores que tuvo Cataluña entre 1717 y 1808, 95 eran foráneos, pues sólo un $22 \%$ de ellos (21 letrados), ocuparon más de una vara en Cataluña. El 78\% (74 letrados) tuvieron bastante con una sola alcaldía mayor (incluidas prórrogas). La situación parecía insólita si pensamos que entre 1750-1808, los foráneos representaban el 60\% (88 alcaldes mayores) y los catalanes el $40 \%$ (58 alcaldes mayores). También es interesante anotar que entre los alcaldes mayores del país también hubo cierta resistencia a la movilidad. Por ejemplo, de los 114 alcaldes catalanes entre 1717-1808, el 24\% (27 letrados) ocuparon varas en otros lugares de España, mayoritariamente en Aragón y.Valencia. En cambio el $76 \%$ (87 letrados) hicieron su carrera sólo en varas catalanas ${ }^{101}$. Respecto a los ascensos a Chancillerías y Audiencias, dejados éstos a la discreción real, la realidad indica que una vez más el camino quedó nuevamente truncado. De todos modos conocemos algunos casos excepcionales. El más notorio fue el de Jorge Puig y Modolell, natural de Puigcerdá. Modolell había comenzado su carrera en Balaguer el año 1756. Más tarde ocupó las alcaldías de Gerona (1765-1767) y Valencia (1767-1770). En el año 1770 fue ascendido a una plaza de alcalde del crimen de la Real Audiencia catalana y en 1775 ascendido a oidor. Años más tarde en 1783 fue nombrado regente de la Audiencia de Mallorca en donde falleció en $1790^{102}$. Epifanio Fortuny era natural de Balaguer, población en la que su familia ocupaba importantes cargos municipales. Primero estuvo desti-

99 ACA: Real Audiencia, reg. 1.012, fols. 286v-287r; Madrid, 5 de septiembre de 1795.

${ }_{100}$ ACA: Real Audiencia, reg. 1.269, fols. 191v-194r; Cádiz, 20 de mayo de 1812.

101 Aunque los datos no son definitivos diremos que entre los alcaldes mayores foráneos sobresalían valencianos y aragoneses para la Corona de Aragón. Escasos eran los mallorquines: Respecto a los súbditos castellanos predominaban: andaluces, extremeños, asturianos, gallegos, murcianos y navarros. Esta información ha sido obtenida del ACA, secciones Cancillería y Real Audiencia, series: Officialium y Diversorum, años 1717-1808.

102 MOlas Ribalta, Pere: «Magistrats de l'Audiència borbònica» en Mayurca (Palma de Mallorca) 22-II (1989), págs. 825-833.

Hispania, LXI/1, núm. 207 (2001) 289-314 
nado en la alcaldía de Villafranca del Penedés (1752-1757). Luego se trasladó a la vara de Lérida (1757-1761), Montblanc (1761-1764) y Tárrega (17701775). En 1786, de la alcaldía mayor alicantina, pasó a ocupar una plaza en la Sala Criminal de la Audiencia, para promocionar posteriormente a oidor en $1791^{103}$. Los catalanes Pablo Jover Placies y Armengol Dalmau y de Cubells son casos que se remontan al primer cuarto del siglo XIX. El primero - Pablo Jover - era desde 1809 alcalde honorario del crimen de la Audiencia de Galicia. Anteriormente había sido alcalde mayor de Tarragona (1794-1804). En el año 1805 renunció a la alcaldía de Antequera, pero aceptó la vara de Murcia. Al finalizar la guerra contra Francia, el rey Fernando VII, por su fidelidad, le nombró en 1815 alcalde del crimen de la Audiencia catalana ${ }^{104}$. Armengol Dalmau y de Cubells era natural de la Seu de Urgel. En febrero de 1825 ocupó, por breve espacio de tiempo, una plaza de alcalde del crimen. Sabemos que había sido alcalde mayor de Barcelona (1806-1808) y Valencia. Ésta última vara bajo la ocupación francesa (1811-1812). Sin embargo Fernando VII le exculpó del delito de colaboración y alta traición, a pesar de los intentos del regidor decano de Barcelona, conde de Creixell. No obstante finalizado el trienio liberal no pudo eludir el arresto domiciliario por simpatizar con la causa liberal ${ }^{105}$.

En cuanto a los no naturales de la Provincia, podemos citar al valenciano José Ferrer de la Puente, alcalde mayor de Manresa (1751-1752) que hizo carrera en las Indias. En 1752 fue nombrado auditor militar de Venezuela. Años más tarde, ascendió a oidor en las Audiencias de Quito (1764) y Lima (1778). Poco después, en 1783, culminó su carrera en la regencia de la Audiencia de Santa Fe de Bogotán ${ }^{106}$.

Juan García de Ávila, andaluz de nacimiento, era un letrado muy experimentado. Había sido alcalde mayor de Tarragona (1769-1770) pero también ejerció las varas de Pucherna (1754), Campillo de Altobuey (1761), San Felipe (1764), Castellón de la Plana (1770) y Valencia (1774). Gracias a su meritorio currículum el rey le nombró en 1777, alcalde del crimen de la Chancillería de Valladolid, para promocionar a una plaza vacante de oidor de la Audiencia valenciana en $1784^{107}$. En cambio el mallorquín, Nicolás Campaner y Satre, comenzó su carrera en las alcaldías de Trujillo (1773-1777), Almería (1777-1781), Ori-

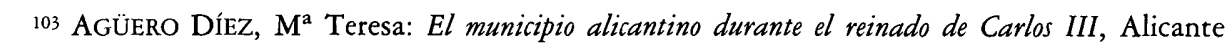
1998, pág. 37.

${ }_{104}$ ACA: Real Audiencia, reg. 1.465, fols. 39-41v; Palacio, 10 de julio de 1815 . Ese mismo año Joaquín López de Olivas, alcalde mayor de Puigcerdá entre 1804 y 1808, era nombrado oidor de la Real Audiencia de Cataluña. Procedía de la vara de Cartagena. Pérez SAmper, María de los Ángeles:«La Real Audiencia de Cataluña durante la guerra de la Independencia» en Pedralbes (Barcelona) 2 (1980), pág. 206.

105 ACA: Real Audiencia, reg. 1.279, fols. 95-96v; Madrid, 25 de abril de 1825.

106 BurKholder, Mark. A y Chandler, D.S: Op. cit., págs. 358,416 y 422.

107 Molas Ribalta, Pere: La Audiencia borbónica del Reino de Valencia (1707-1834), Alicante 1999, pág. 49. 
huela (1781-1785) y Tortosa (1786-1793). En 1792 recibió honores de alcalde del crimen de la Audiencia de Aragón, ocupando un año después el corregimiento de Chinchilla. No finalizó el sexenio porque en 1794 se le nombró oidor en la Real Audiencia de Mallorca (1794-1812)108. El gallego Pedro José Menduiña, fue alcalde mayor de Montilla del Palancar (1794) y de Camprodón (1802). En 1814 fue ascendido a ministro civil de la Real Audiencia catalana ${ }^{109}$. Más lejano resulta el nombramiento de Francisco del Castillo Valero, alcalde mayor de Barcelona en 1815. De él sólo sabemos que se incorporó a la Audienca de Extremadura hacia $1826^{110}$. Más curiosa resulta la carrera de Manuel Gutiérrez Bustillo, alcalde mayor de Camprodón (1789-1794). Gracias a los méritos contraidos en la defensa de la villa durante la guerra con Francia, fue nombrado fiscal del crimen de la Audiencia de Cataluña (1794-1809). Posteriormente, su resistencia a jurar rey a José I Bonaparte y su confinamiento en Francia, le valió ser designado regente de la Chancillería de Valladolid el año $1813^{111}$.

Curiosamente para compensar los escasos ascensos de alcaldes mayores a tribunales superiores, el rey aumentó los nombramientos honoríficos de alcaldes del crimen de la Audiencia de Cataluña. Estas dignidades ya las habían disfrutado otros alcaldes mayores como José Francisco de Alós y Rius que recibió honores de oidor (1728) y de consejero de Castilla (1749) y Jacinto Tudó, alcalde honorario del crimen en 1760. La mayoría de honores referidos están fechados entre 1789-1790 (después de las Cortes de 1789) y se concedieron como colofón a una dilatada carrera profesional en corregimientos y alcaldías. Estos honores conllevaban ciertos privilegios como el tratamiento de "señoría" en vez de "merced", que era el que recibían todos los alcaldes mayores ${ }^{112}$. No tenían derecho a sueldo de magistrado ni asiento en la Sala Criminal, pero era un paso importante para acceder - algún día - a una plaza vacante en la $\mathrm{Au}-$ diencia. Aunque no siempre se cumplieron estas expectativas. El primero de ellos, Gaspar Jover y Teres, natural de Tárrega, era alcalde mayor de tercera clase en Barcelona (1788-1798), cuando recibió honores de alcalde del crimen $^{113}$. Su experiencia era importante pero se limitaba a varas de desigual categoría en Cataluña, Aragón y Valencia; como Agramunt (1762), Camprodón (1766), Manresa (1770), Lérida (1775), Huesca (1780) y San Felipe (1783). Semejante era el "cursus bonorum" del letrado valenciano Antonio Alcaide, alcal-

108 Molas Ribalta, Pere:«Las Audiencias borbónicas en la Corona de Aragón», pág. 163.

109 ACA: Real Audiencia, reg. 1.465, fols. 3v-4r; Palacio, 9 de marzo de 1814.

110 ACA: Real Audeincia, reg. 1.280, fols. 323v-330r; Barcelona, 22 de julio de 1826.

111 ACA: Real Audiencia, reg. 1.187, fols. 158-161v; Madrid, 25 de julio de 1789. Ibidem., reg. 989, fols. 252v-254r; Aranjuez; 20 de junio de 1794. Pérez SAMPER, María de los Ángeles: Op. cit., págs. 200-206. MARTín POSTIGO, María de la Soterraña: Los presidentes de la Real Chancillería de Valladolid, Valladolid, 1988, págs. 129-130

112 ACA: Real Audiencia, reg. 1.165, fols. 219-223r; Barcelona, 11 de diciembre de 1800.

113 ACA: Real Audiencia, reg. 989, fols. 188v-189r; Madrid, 11 de diciembre de 1789. 
de mayor de Mataró entre 1784 y $1791^{114}$. Anteriormente había ocupado las varas de Berga (1762), Calatayud (1769), Teruel (1775) y San Felipe (1780). Al finalizar su sexenio en Mataró se hizo cargo de la tenencia de la Coruña (1791) en donde se jubilón ${ }^{115}$. Antonio Sala Torres de Bages, alcalde mayor de Tarragona (1787-1793), había ejercido la la vara de Mataró entre 1778 y $1782^{116}$. Pero sólo pudo ocupar alcaldías mayores como las de Granollers (1762) y Manresa (1782), renunciando en el año 1786 a la vara que se le ofreció en Huesca. Francisco Carballo de Ledesma, alcalde mayor de Vic (17841790 ), es un caso singular ${ }^{117}$. Sabemos que nació en Santa Fe (obispado de Buenos Aires), por lo tanto fue la única aportación de las colonias americanas a las varas catalanas ${ }^{118}$. Muy joven debió de llegar a Cataluña, pues estudió derecho en Cervera. Pero como muchos de sus compañeros se especializó en varas del país: Berga (1770), Villafranca del Penedés (1774), Manresa (1777) y Gerona (1790) ${ }^{119}$. Miguel Serrano Belézar, alcalde mayor de Balaguer (1790), recibió honores de la Audiencia en 1796, pasando ese año a corregidor de Fra$\mathrm{ga}^{120}$. En cambio el tortosino José Cayetano Garcini y Salomó obtuvo honores de alcalde del crimen en 1802, después de la visita de Carlos IV a Barcelona ${ }^{121}$. Por entonces era alcalde mayor más antiguo de Barcelona (1799-1806). Había desempeñado algunos empleos menores como el de alcalde de cuartel (1792 y 1797) y el de asesor subdelegado del cuerpo de artillería (1794). Al cesar en la alcaldía no volvió a ocupar vara alguna. Puede parecer extraño un nombramiento como el suyo que difiere del perfil profesional del resto de alcaldes mayores, pero se entiende gracias a sus buenas conexiones familiares. Su primo, José Garcini de Queralt, era alcalde del crimen (1792) y oidor (1801) en la Chancillería de Granada ${ }^{122}$. Además un hermano de éste, el caballero de la orden de Santiago, Ignacio Garcini de Queralt, fue intendente de Aragón (1805) y protegido de Godoy ${ }^{123}$. Otros alcaldes mayores que sirvieron varas catalanas, pero que recibieron honores de otros tribunales, son el alicantino Máximo Terol y Doménec, corregidor letrado de Alcira (1783-1792), en cuya plaza fue nombrado, en el año 1789, ministro honorario de la Real Audiencia valencia-

114 ACA: Real Audiencia, reg. 989, fols. 191v-193r; Madrid, 21 de enero de 1790.

115 GIMÉNEZ LÓPEZ, Enrique: Op. cit., págs. 181-188.

116 ACA: Real Audiencia, leg. 216, «Minutas de juramentos para honores de alcalde del crimen»; Barcelona, 15 de abril de 1790 .

117 ACA: Real Audiencia, reg. 989, fols. 189v-190r; Madrid, 10 de diciembre de 1789.

118 PAZ, Ramón: Índice de relaciones de méritos y servicios conservados en la sección de Consejos, Madrid 1943, pág. 235.

119 GÓMEZ RIVERO, Ricardo: Op. cit., 67, págs. 494-495.

120 ACA: Real Audiencia, reg. 989, fols. 270v-271r; Aranjuez, 11 de abril de 1796.

121 ACA: Real Audiencia, reg. 989, fols. 344-345v; Madrid,12 de noviembre de 1802.

122 GAN GIMÉNEZ, Pedro: La Real Chancillería de Granada (1505-1834), Granada 1988, pág. 246.

${ }^{123}$ ABBAD, Fabrice y OzANAM, Didier: Les intendants espagnols du XVIII siècle, Madrid 1992, págs. 95-96.

Hispania, LXI/1, núm. 207 (2001) 289-314 
na ${ }^{124}$. Poco antes había sido alcalde mayor de Camprodón (1770-1773). Acabado su mandato en Alcira, se trasladó al corregimiento de Ciudad Real (1792) y luego a una de las dos varas de Cádiz (1798). Los navarros Bernardo Óscoz y Larraínzar y Pedro Mendieta y Murga, alcaldes mayores de segunda y tercera clase de Barcelona respectivamante, obtuvieron también en 1789 honores de alcalde criminal, pero de la Real Chancillería de Granada. El mencionado Nicolás Campaner y Sastre, alcalde mayor de Tortosa, recibió honores de alcalde del crimen de la Audiencia de Aragón en 1792. Este letrado fue substituido en la vara por el alavés, Manuel Ortiz de Pinedo (1793-1799), el cual poco después se hizo cargo de la alcaldía de Salamanca. En el año 1815 recibió honores de alcalde criminal de la Chancillería de Valladolid ${ }^{125}$. En cuanto al letrado andaluz, José Mariano Marqués y Aguilar, alcalde mayor de Mataró (1815-1820), sólo diremos para finalizar, que consiguió sus honores de ministro honorario de la $\mathrm{Au}-$ diencia de Extremadura en $1818^{126}$.

\section{CONCLUSIÓN}

Como hemos podido observar el empleo de alcalde mayor en Cataluña no fue un destino fácil para sus titulares. Muchas eran las deficiencias que tenían y pocos los atractivos. Posiblemente la explicación se deba a las circunstancias precipitadas con que la Nueva Planta los introdujo siguiendo el modelo castellano. No resulta sencillo responder hasta que punto esta magistratura se adaptó al complejo marco jurisdiccional catalán. No olvidemos que la existencia, a nivel local, de otras justicias ordinarias como el baile y el corregidor —-su más inmediato superior jerárquico-, fueron elementos que delimitaron su campo de actuación. Sin olvidar la sumisión a la Real Audiencia y las interferencias que ocasionaban la existencia de otros tribunales reales y baronales. Aun así serios fueron los intentos por profesionalizarlos, adaptarlos a la novedad del Reformismo ilustrado y procurarles mejores salidas profesionales. A la postre esto sólo fue posible con un reducido grupo de afortunados letrados. Aunque no por ello — creemos - deben ser infravaloradas las alcaldías catalanas, que si

\footnotetext{
124 MOlas Ribalta, Pere: La Audiencia borbónica del Reino de Valencia (1707-1834), págs. 95-96.

125 Otros casos documentados son el de Francisco Manuel Laborda, alcalde mayor de Igualada (1765) y corregidor de Logroño. Fue alcalde honorario del crimen de la Audiencia aragonesa en 1786. Pedro Santonja, alcalde mayor de Igualada, Camprodón, San Felipe, corregidor de Benavarre y Segovia, consiguió honores de ministro de la Chancillería de Valladolid (1789). Antonio Riera y Roger, también ejerció las varas de Igualada, Morella, Tortosa, Palma, corregimiento de Logroño y alcalde mayor de Valencia de cuya Real Audiencia recibió honores de alcalde del crimen en 1798. Al igual que Antonio Quer y Villaró de Anglada alcalde mayor de Agramunt, Balaguer, Besalú, Navas del Rey y Córdoba, premiado con honores de la Audiencia sevillana en 1802. GómEz RIVERO, Ricardo: Op. cit., 67, págs. 46, 108, 128, 150, 168, 174, 178 y 192 .

${ }_{126}$ ACA: Real Audiencia, reg. 1.465, fols. 123-125r; Palacio, 24 de agosto de 1818.
}

Hispania, LXI/1, núm. 207 (2001) 289-314 
bien gozaron de pocas oportunidades promocionales, jugaron un papel fundamental en la vida judicial y municipal de la Cataluña del siglo XVIII, algunos de cuyos fundamentos siguen siendo vigentes hoy en día. 